\title{
Actual trends in palliative oncologic surgery
}

\author{
G Patrizi , G Miscusi, F Pelle, G Di Rocco, L Venturini, D Giannotti, F Frezzotti, R Giordano, A Redler \\ From XXIII Annual Meeting of the Italian Society of Geriatric Surgery \\ Lecce, Italy. 2-4 December 2010
}

\section{Background}

Geriatric oncologic surgery is frequently based on palliative treatments. Few studies focus on the advantages and pitfalls of surgical versus endoscopic palliation in oncological surgery. The reviews published on this topic and a statistical non-specific general profile of our Institution's experience may depict a realistic and current general trend.

\section{Materials and methods}

Data from the literature were revised, focusing our attention on published reviews on surgical and endoscopic palliation for oesophagus, colon-rectum and pancreatic-biliary cancers. We also obtained the data from the registries of our hospital on these very diagnoses. Finally, we requested the number of metallic stents sold in Italy and in Europe to one of the main manufacturers, assuming that almost all of them are for oncological palliation.

\section{Results}

Even though most of the published reviews conclude favorably for a surgical palliation, the general trend appears to be more and more oriented towards the endoscopic palliation with stents. Little was written on the potential role of laparoscopy for surgical palliation.

\section{Conclusions}

There is a growing request for endoscopic treatments, strengthened by a prioritary scientific interest and technological development in this field, with growing responsibility for endoscopists and interventional radiologists.

\footnotetext{
* Correspondence: g_patrizi@yahoo.com Dipartimento di Scienze Chirurgiche, Policlinico Umberto I, Università di Roma"La Sapienza", Rome, Italy
}

Published: 24 August 2011

doi:10.1186/1471-2318-11-S1-A40

Cite this article as: Patrizi et al:: Actual trends in palliative oncologic surgery. BMC Geriatrics 2011 11(Suppl 1):A40.
Submit your next manuscript to BioMed Central and take full advantage of:

- Convenient online submission

- Thorough peer review

- No space constraints or color figure charges

- Immediate publication on acceptance

- Inclusion in PubMed, CAS, Scopus and Google Scholar

- Research which is freely available for redistribution

Submit your manuscript at www.biomedcentral.com/submit

\section{() Biomed Central}

\section{Biomed Central}

